\title{
Comparative study on compatibility and growth response of pear varieties on different rootstocks at nursery
}

\author{
Javed Rahman ${ }^{1 *}$, Murad Aftab ${ }^{2}$, Mohammad Abdul Rauf ${ }^{1}$, Khalil Ur \\ Rahman $^{1}$, Wasim Bilal ${ }^{1}$, Farooq $^{1}$ and Gohar Ayub ${ }^{2}$ \\ 1. Agricultural Research Institute, Mingora Swat, Khyber Pakhtunkhwa-Pakistan \\ 2. Department of Horticulture, The University of Agriculture Peshawar-Pakistan \\ *Corresponding author's email: javedmiandam@gmail.com \\ Citation \\ Javed Rahman, Murad Aftab, Mohammad Abdul Rauf, Khalil Ur Rahman, Wasim Bilal, Farooq and Gohar Ayub. \\ Comparative study on compatibility and growth response of pear varieties on different rootstocks at nursery. Pure \\ and Applied Biology. Vol. 6, Issue 1, pp286-292. http://dx.doi.org/10.19045/bspab.2017.60026
}

\begin{tabular}{llll}
\hline \hline Received: 09/12/2016 & Revised: 16/02/2017 & Accepted: 22/02/2017 & Online First: 26/02/2017 \\
\hline
\end{tabular}

\section{Abstract}

Grafting is an asexual method of reproducing fruit plants. The selection of proper rootstock and suitable variety is imperative in order to assure scion and root stock compatibility. Therefore, the present experiment was carried out to evaluate the comparative study on compatibility and growth response of pear varieties on different rootstocks at nursery of the Agricultural Research Institute (North), Mingora Swat, Pakistan during the year 2014. Six pear cultivars (four exotic such as William, Santa Maria, Hosuai and Shinsui and two indigenous such as Khan Tango and Shaghuri) were grafted on two rootstocks (Quince and Pyrus pashia L., locally known as tangai). Pear varieties, rootstocks and their interaction showed significant variation for all the studied attributes. Variety William showed higher graft take success $\%$, plant height, number of shoots plant $^{-1}$ and survival percentage. However, lower number of graft take success $\%$, plant height, plant diameter, number of shoots plant $^{-1}$ and survival percentage were observed on Quince rootstocks. It was concluded that pear variety William could be grafted on Quince rootstock for high graft take success and better growth response.

Keywords: Grafting; Pear varieties; Rootstocks; Survival

\section{Introduction}

Pears (Pyrus communis L. and Pyrus pyrifolia L.) are important pome fruit, belongs to family Rosaceae. In Pakistan, pear orchards are found on the terraces or hilly areas and in the plan of Khyber Pakhtunkhwa like Mardan, Peshawar and Hazara. Pear is generally propagated through asexual or vegetative mean in which grafting and budding is the most appropriate method of propagation. In Pakistan the farmers use whip and cleft grafting. Farmers use seeds of Tangai (Pyrus pashia L.) and Quince as a rootstock [1]. East Malling Research Station found Quince as a rootstock, which is used for dwarfing pear cultivars [2].

In the recent years, interest in the introduction of new pear varieties has been emerged, which is very much important for opening new ways of trade and to fulfil the demand of consumers [3] New vistas has 
been opened with the rapid technology development of rootstock (propagation of asexual/clonal rootstock) and nursery of fruit trees [4].

Several factors are identified, which may affect success of grafting in the woody species like season, environment, grafting techniques, graft capability among scions, rootstocks and genotypes. Techniques and season of grafting seem to be useful for the purpose of graft success in various genotypes [5]. Different rootstocks of pear and quince have been used for the production of pear on commercial scale. Recommendation of Quince as a rootstock is useful for quality fruit production and due to the nature of small size of tree, harvesting and other cultural practices are easy to manage [6].The rootstocks of Quince are extensively used for various varieties of Pear. Several varieties of pear showed incompatibility when grafted on Quince [5, 7].

The current study is focused to evaluate the compatibility and graft take success of different pear varieties on two rootstocks.

\section{Materials and method}

An experiment on "comparative study on compatibility and growth response of pear varieties on different rootstocks" was carried out at the Agricultural Research Institute, Mingora, Swat (Pakistan) during winter 2014. The aim of the study was to test the compatibility of pear cultivars to different rootstocks. The experiment consisted of two factors such as cultivars and rootstock. Six cultivars namely William, Santa Maria, Hosai, Shinsui (exotic), Khan Tango and Shaguri (indigenous) were grafted on two rootstock such as Quince and Pyrus pashia L., locally known as tangai. The experiment was carried out in Randomized Complete Block Design (RCBD) with three replications. Scions and rootstock of similar size were selected. Tongue grafting was practiced in the month of February, 2014 and were planted in the field on the same date. Row-to-row and plant-to-plant distance was kept 60 and $30 \mathrm{~cm}$, respectively. The data on vegetative attributes were recorded in December, 2014. Percent graft take success was evaluated by the successful sprouting and growth of scion by the formula given as:

$\%$ Graft take success $=$ Number of successful graft $\times 100$ Total number of plants grafted

Whereas, plant height was determined in $\mathrm{cm}$ with the help of measuring tape, diameter was recorded in $\mathrm{mm}$ by the use of digital Vernier caliper and branches per plant were counted in each sprouted scion.

\section{Statistical analysis}

The data noted were subjected to analysis of variance (ANOVA) and least significant difference (LSD) test at $1 \%$ probability was used for mean differences [8].

\section{Results and discussion}

Grafts take success (\%)

Changes in pear graft take success $\%$ due to varieties and rootstocks are reported in Table 1. Significant variation was observed in graft take success \% due to verities and rootstock. The $\mathrm{V} \times \mathrm{R}$ interaction was also found significant. William variety resulted in higher graft take success (88.94\%), followed by Khan Tango variety $(80.44 \%)$ while graft take success \% was lower in plots sown with Shinsui variety $(65.27 \%)$. Moreover, Quince rootstock resulted in higher graft take success $(84.46 \%)$ as compared to Local (Tangai) variety $(69.40 \%)$. The $\mathrm{V} \times \mathrm{R}$ interaction revealed that the performance of all varieties except Shinsui were superior on Quince root stock than Local root stock (Figure 1). However, Shinsui showed similar result for graft take success \% on both root stocks. Overall, higher graft take success \% was observed in Shaguri variety grafted on Quince root stock. High graft take success in Quince might be due to the compatibility of scion with rootstock as the genetic makeup of each scion and rootstock varies. Significant 
variation was recorded in graft take success of various apple cultivars [9]. The results are also supported by [10], who investigated high bud take success in nursery plants of apple.

Table 1. Graf take success $(\%)$, plant height $(\mathrm{cm})$, plant diameter $(\mathrm{mm})$, number of shoots plant ${ }^{-1}$ and survival percentage $(\%)$ of pear graftage as influenced by varieties and rootstock

\begin{tabular}{|l|c|c|c|c|c|}
\hline Pear varieties & $\begin{array}{l}\text { Graf take } \\
\text { Success }\end{array}$ & $\begin{array}{l}\text { Plant height } \\
(\mathbf{c m})\end{array}$ & $\begin{array}{l}\text { Plant diameter } \\
(\mathbf{m m})\end{array}$ & $\begin{array}{l}\text { Number of } \\
\text { shoots plant }\end{array}$ & $\begin{array}{l}\text { Survival } \\
\text { Percentage } \\
(\%)\end{array}$ \\
\hline William & $88.94 \mathrm{a}$ & $91.62 \mathrm{a}$ & $13.75 \mathrm{bc}$ & $5.50 \mathrm{a}$ & $73.10 \mathrm{a}$ \\
\hline Santa Maria & $73.83 \mathrm{c}$ & $75.17 \mathrm{c}$ & $13.48 \mathrm{c}$ & $2.30 \mathrm{c}$ & $44.55 \mathrm{~d}$ \\
\hline Hosai & $72.55 \mathrm{c}$ & $43.98 \mathrm{e}$ & $10.97 \mathrm{~d}$ & $1.83 \mathrm{~d}$ & $47.76 \mathrm{c}$ \\
\hline Shinsui & $65.27 \mathrm{~d}$ & $31.82 \mathrm{f}$ & $9.83 \mathrm{e}$ & $3.00 \mathrm{~b}$ & $49.61 \mathrm{~b}$ \\
\hline Shaghuri & $80.55 \mathrm{~b}$ & $73.57 \mathrm{~d}$ & $14.28 \mathrm{ab}$ & $1.30 \mathrm{e}$ & $49.63 \mathrm{~b}$ \\
\hline Khan Tango & $80.44 \mathrm{~b}$ & $84.93 \mathrm{~b}$ & $14.81 \mathrm{a}$ & $1.60 \mathrm{~d}$ & $48.63 \mathrm{bc}$ \\
\hline LSD at 1\% & 4.51 & 2.01 & 0.86 & 0.33 & 1.83 \\
\hline \multicolumn{7}{|c|}{ Root stocks } & \\
\hline Quince & $84.46 \mathrm{a}$ & $73.69 \mathrm{a}$ & $13.18 \mathrm{a}$ & $2.77 \mathrm{a}$ & $55.91 \mathrm{a}$ \\
\hline Local (Tangai) & $69.40 \mathrm{~b}$ & $60.00 \mathrm{~b}$ & $12.53 \mathrm{~b}$ & $2.40 \mathrm{~b}$ & $48.51 \mathrm{~b}$ \\
\hline Significance Level & $\mathrm{S}$ & S S & S & S \\
\hline \multicolumn{7}{|l|}{ Interactions (Varieties $\times$ Root stocks) } \\
\hline LSD at 1\% & 6.38 & 2.84 & 1.21 & 0.46 & 2.58 \\
\hline
\end{tabular}

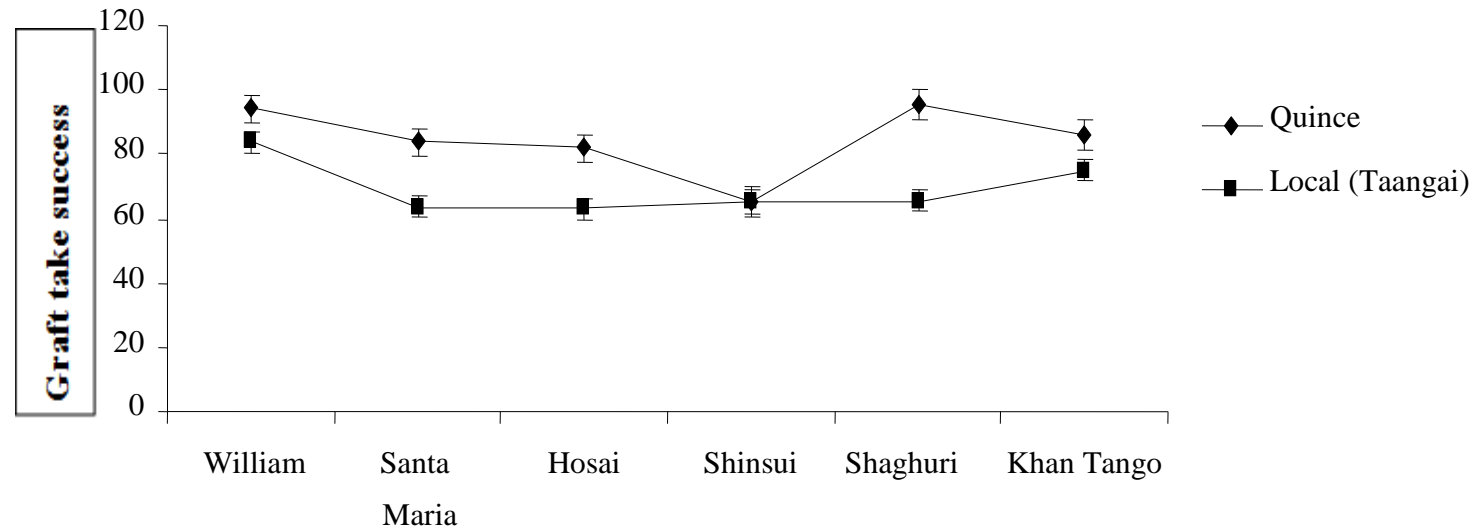

Pear Varieties

Figure 1. Graft take success of pear varieties as affected by rootstocks

\section{Plant height (cm)}

The significant results showed that maximum plant height $(73.69 \mathrm{~cm})$ was exhibited by pear varieties grafted on Quince, while the minimum plant height $(60.00 \mathrm{~cm})$ was recorded on rootstock
Taangai. Pear varieties also showed significant difference, where more plant growth $(91.62 \mathrm{~cm})$ was recorded in pear variety William, while Shinsui variety of pear showed the lowest plant height (31.82 $\mathrm{cm}$ ) (Table 1). As concerned interaction 
more plant height was recorded in pear variety William, when grafted on Quince. However, the grafting of pear variety Hosai on Local Taangai (Pyrus pashia L.) gave the least plant height (Figure 2).

Vegetative growth and graft compatibility in nursery plants is based on the genetic constitution of species or varieties and root stocks [11]. In addition, differences in plant height are attributable to the effect of different level and proportion of auxin and cytokinin found in the apical meristems of pear varieties [12]. Furthermore, [13] reported that Quince as a rootstock is better for grafting different varieties of pear, as it affect the height of pear plant. Studies on the scion and rootstock of apples showed that rate of growth is more affected by rootstock than scion, while the growth duration is highly affected by scion [14].

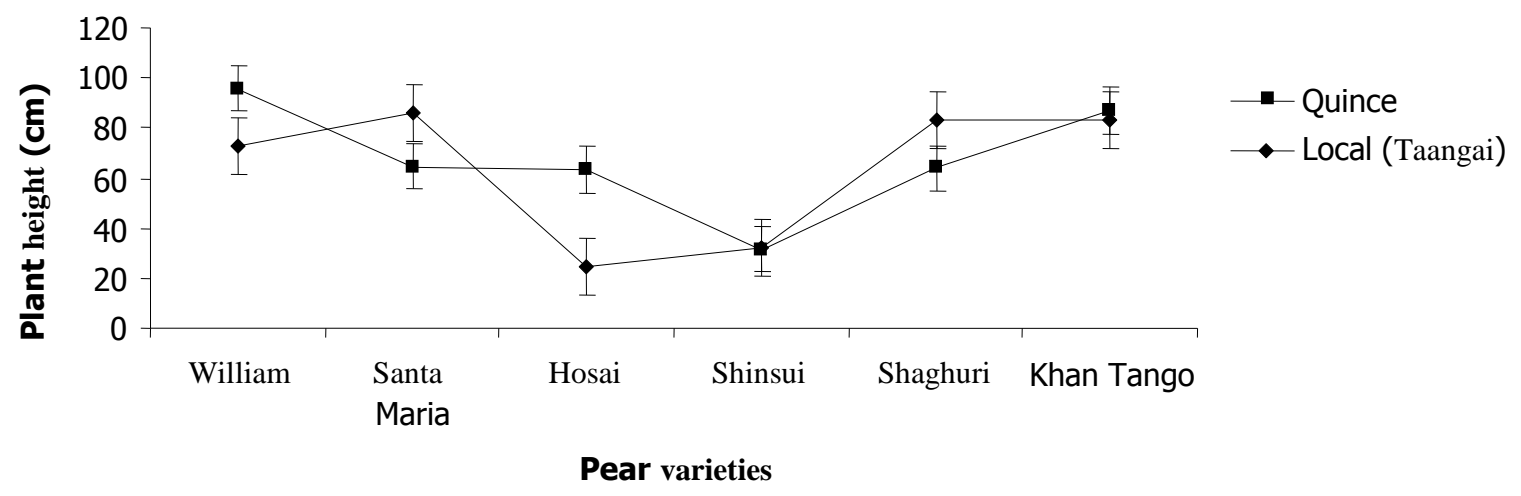

Figure 2. Plant height $(\mathrm{cm})$ of pear varieties as affected by rootstocks

\section{Plant diameter (mm)}

The significant data regarding plant diameter indicated that maximum plant diameter $(13.18 \mathrm{~mm})$ was observed on Quince, whereas local (Taangai) showed minimum plant diameter $(12.53 \mathrm{~mm})$. As concerned pear varieties, Khan Tango attained maximum plant diameter (14.81 $\mathrm{mm}$ ), which significantly varied from the rest of the treatments. Whereas, the minimum plant diameter $(9.83 \mathrm{~mm})$ was observed in pear variety Shinsui (Table 1). As for as interaction is concerned, more plant diameter was recorded in pear variety Khan Tango grafted on local (Taangai) of pear. While the grafting of pear variety
Shinsui on Local (Taangai) attained the least plant diameter (Figure 3).

The effect of rootstock on plant diameter was observed and Quince was found to have maximum plant diameter. These results are in conformity with the findings of [15]. It was also reported that more roots can cause maximum scion thickness [16], as they can absorb sufficient nutrients, which can be utilized for further growth and development. Moreover, the scion growth has been observed to be influenced by the graft height on the stem [17] and the same pattern in the girth of scion and rootstock was also noted in apple cultivars [18]. 


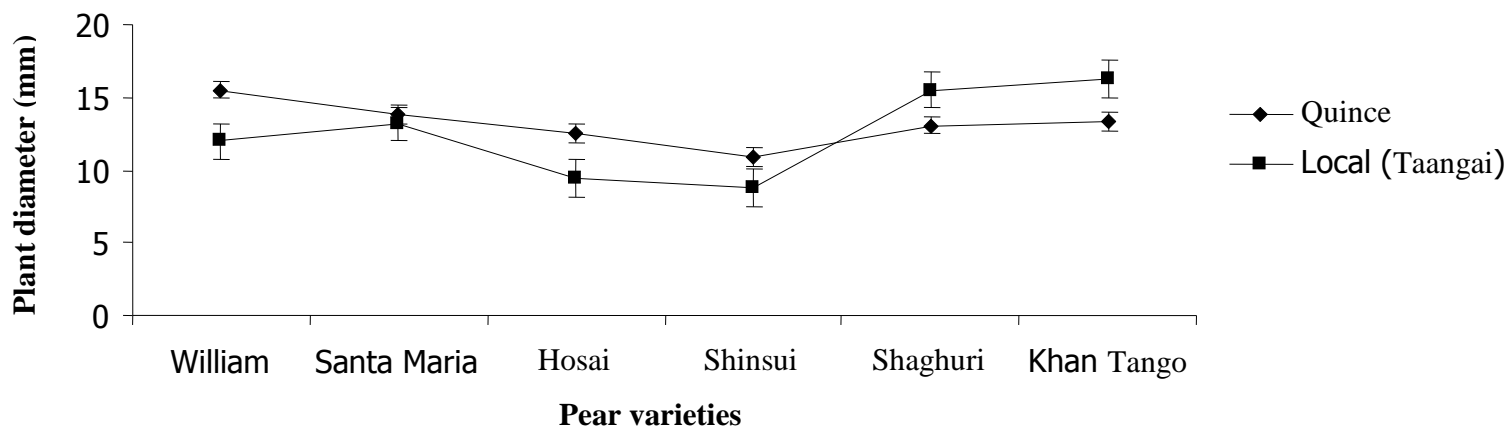

Figure 3. Plant diameter $(\mathrm{mm})$ of pear varieties as affected by rootstocks

\section{Number of shoots plant ${ }^{-1}$}

The significant data regarding number of shoots plant $^{-1}$ indicated that maximum number of shoots plant ${ }^{-1}$ (2.77) were produced on rootstock Quince. However, local (Taangai) exhibited less number of shoot plant ${ }^{-1}$ (2.40). In pear varieties William produced maximum number of shoots plant ${ }^{-1}$ (5.50), which significantly varied from Shinsui (3.00). The minimum number of shoots plant ${ }^{-1}$ (1.30) were observed in pear variety Shaghuri (Table 1). The interaction between varieties and rootstocks showed more number of shoots plant $^{-1}$ in pear variety William, grafted on Quince rootstock. While the grafting of pear variety Shaghuri on Quince produced the least number of shoot plant $^{-1}$ (Figure 4).

According to [19], apple variety on dwarf rootstock produced more shoots as it has the habit of forming bush and espalier. The more shoots may also be due to the maximum plant growth. Moreover, different varieties and rootstock has different kind of growth habit that might have affected number of shoots.

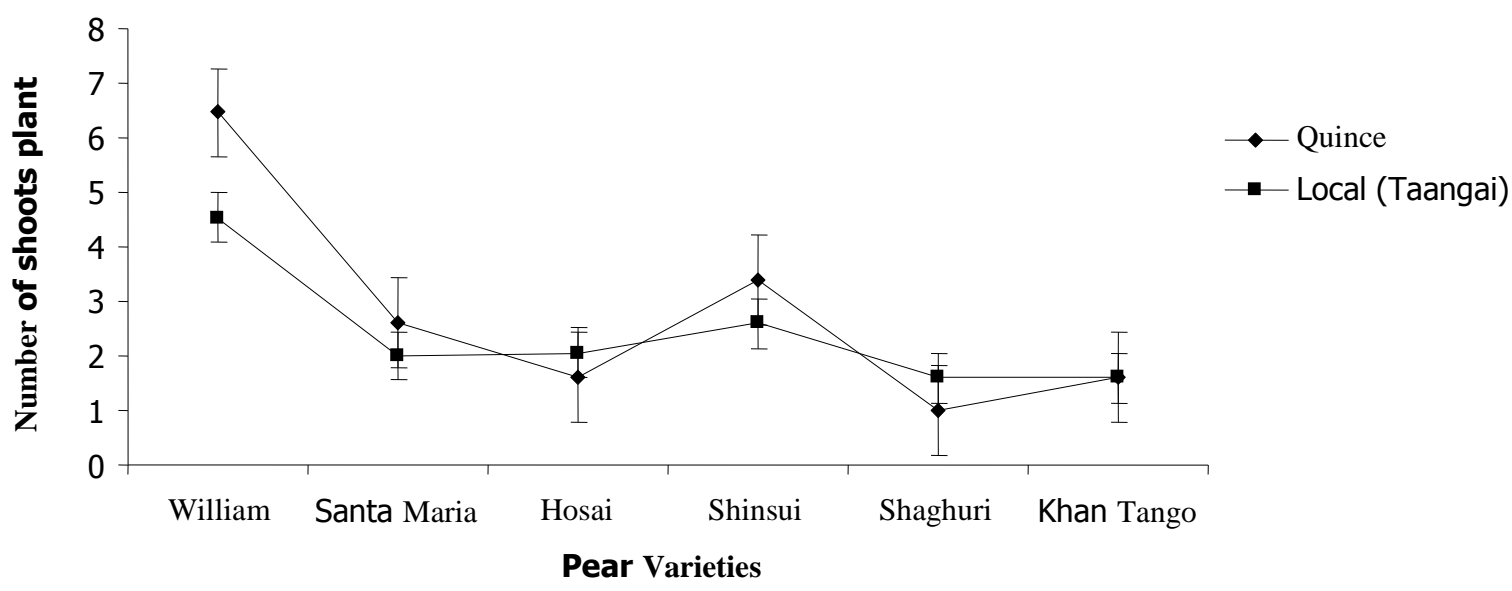

Figure 4. Number of shoots plant ${ }^{-1}$ of pear varieties as affected by root stock 


\section{Survival percentage $(\%)$}

The significant data showed that maximum survival percentage (55.91\%) was observed on Quince, while local (Taangai) rootstock showed least survival percentage (48.51\%). Pear variety William showed maximum survival percentage $(73.10 \%)$. The lower survival percentage $(44.55 \%)$ was observed in pear variety Santa Maria (Table 1). The interaction between varieties and rootstocks showed more number of shoots plant ${ }^{-1}$ in pear variety William, grafted on Quince.
While the grafting of pear variety Santa Maria on Quince rootstock produced the least number of shoot plant ${ }^{-1}$ (Figure 5).

Survival percentage of graft was highly affected in mango by varieties and rootstocks [20]. Rom and Carlson [2] grafted various varieties of pear on Quince and found significant variation for survival percentage and concluded that grafting is a best way to propagate seedlings of quince which results in high graft survival.

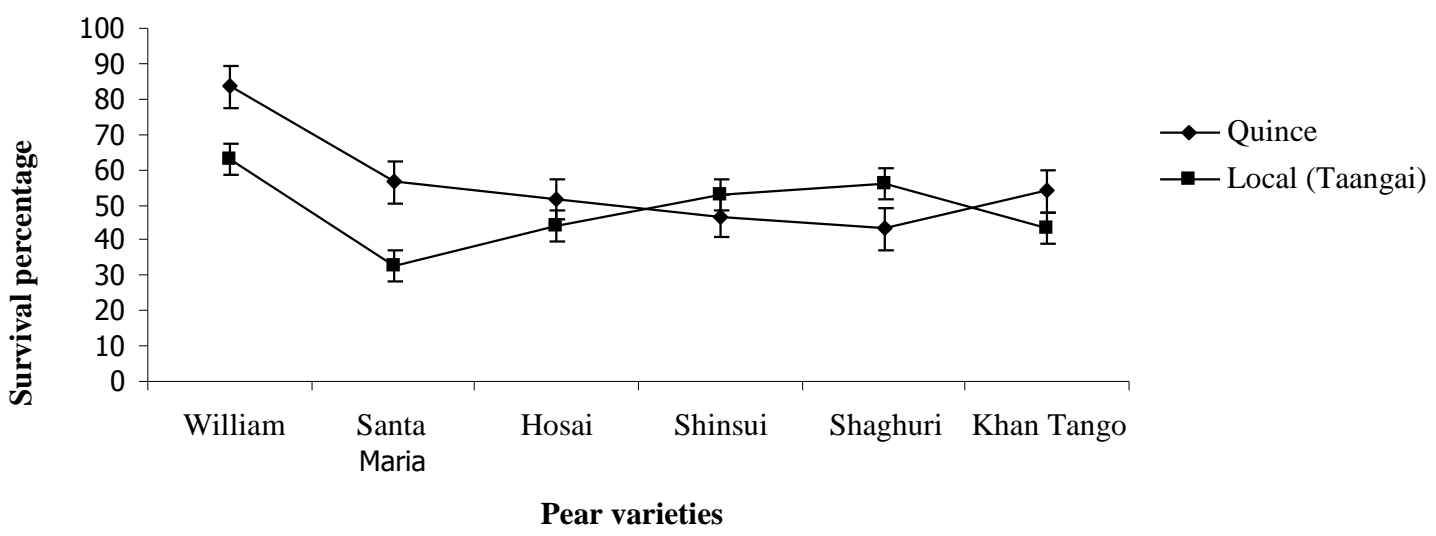

Figure 5. Survival percentage (\%) of pear varieties as affected by rootstock

\section{Conclusions}

On the basis of the study, it is concluded that variety William resulted in higher graft take success $\%$, plant height, number of shoots plant $^{-1}$ and survival percentage. Furthermore, more number of graft take success $\%$, plant height, plant diameter, number of shoots plant $^{-1}$ and survival percentage were observed on Quince rootstocks. Therefore grafting variety William specifically and other varieties in general on Quince root stock is recommended for producing true to type pear nursery plants with improved growth at highest rate of success.

\section{Authors' contributions}

Conceived and designed the experiments: J Rahman, MA Rauf \& G Ayub, Performed the experiments: J Rahman \& M Aftab,
Analysis of the data: Farooq \& KU Rahman, Contributed reagents/ materials/ analysis tools: MA Rauf, Wrote the paper: W Bilal \& M Aftab.

\section{References}

1. Chaudhary MI (2009). A text books of Horticulture. Malik, MN, Bashir E and Bntel R (eds.) pp 472-474.

2. Rom RC \& Carlson RF (1987). Rootstock for Fruit Crops, a Wiley- Interscience publication, New York. USA.

3. Galvis-Sanchez AC, Gil-Izquierdo A \& Gil MI (2003). Comparative study of six pear cultivars in terms of their phenolic content, vitamin $\mathrm{C}$ and antioxidant capacity. J Sci Food Agric 83: 995-1003.

4. Koc A \& Bilgener S (2013). Morphological characterization of 
cherry rootstock candidates selected from Samsun Province in Turkey. Turk J Agric 37: 575-584.

5.Ermel FF, Kervella J, Catesson AM \& Poessel JC (1999). Localized graft incompatibility in pear/quince (Pyrus communis/Cydonia oblonga) combination: multivariate analysis of histological data form 5-month-old grafts. Tree Physiol 19: 645-654.

6.Ozturk A \& Ozturk B (2014).The rootstock influences growth and development of 'Deveci' Pear. Turk J Agric and Natural Sci 1: 1049-1053.

7.Errea P, Felipe A \& Herrero M (1994a). Graft establishment between compatible and incompatible Prunus spp. $J$ Exp Bot 45: 393-401.

8. Steel RGD, Torrie JH \& Dickey DA (1997). Principles and Procedures of Statistics. Abionomial Approach. 3rd Edition. McGraw Hill Companies, Inc. New York, USA.

9.Iqbal J, Jan I, Rahman IU, Shah SHA, Iqbal S, Khan S, Shah S, Ahmad A, Khan AA, Khan A \& Karim W (2016). Effect of Scion on Grafting Success and Other Characteristics of Apple Fruit. American-Eurasian J Agric \& Environ Sci 16 (4): 663-665.

10. Haq I, Hussain A \& Ali N (1985). Influence of nitrogen on bud take and growth of apple nursery planting. Sarhad J Agric 1(2): 433-435.

11. Lauri PE, Maguylo K \& Trottier C (2006). Architecture and size relations: an essay on the apple (Malus $\times$ domestica, Rosaceae) tree. Am J Bot 93: 357-368.

12. Wang SY, Faust M \& Line MJ (1994). Apical dominance in apple (Malus domestica borkh). The possible role of indole-3-acetic acid. J Amer Soc Hort Sci 119: 1215-1221.

13. Milosevic T \& Milosevic N (2011). Influence of cultivar and rootstook on early growth and syllepsis in nursery trees of pear (pyrus communis L.Rosaceae). Braz Arch Biol Technol 54 (3).

14. Vyvyan MC (1955). Interrelation of scion and rootstock in fruit-trees. I. Weights and relative weights of young trees formed by the reciprocal unions, as scion and rootstock, of three apple rootstock varieties: M.IX, M.IV, and M.XII. Ann Bot 75: 401-423.

15. Omer FK \& Kalyoncu IH (2011) Nursery growing of some apple varieties using different grafting methods in greenhouse and orchard. Afric J Biotech 10(83): 19375-19384.

16. Lord WJ (1983). Scion/root stock and interstems effect on growth nutrition and fruiting of apple trees and fruit quality. Hort Abst 53(8): 552.

17. Parry MS (1986). The effect of budding height on the field performances of two apple cultivars on three rootstocks. $J$ Hortic Sci 61: 1-7.

18. Tworkoski T \& S Miller (2007). Rootstock effect on growth of apple scions with different growth habits. Scientia Hort 111(4): 335-343.

19. Susan F (2012). Rootstocks for Fruits. Royal Hort Soci pp. 1-4.

20. Pio R, Chagas EA, Barbosa W, Tucci MLS, Mourao Filho FDAA \& Campagnolo MA (2010). Production of quince nursery trees by different grafting methods. Ciencia Rural, Santa Maria 40(5): 1049-1052. 